\title{
DÜBLIN
}

Technological University Dublin

ARROW@TU Dublin

\section{Economic appraisal of hybrid solar-biomass thermophotovoltaic power generation}

\author{
C. M. Iftekhar Hussain cmih \\ Technological University Dublin, iftekhar.hussain@mydit.ie \\ Aidan Duffy \\ Technological University Dublin, aidan.duffy@tudublin.ie \\ Brian Norton \\ Technological University Dublin, brian.norton@tudublin.ie
}

Follow this and additional works at: https://arrow.tudublin.ie/dubencon2

Part of the Civil Engineering Commons, and the Energy Systems Commons

\section{Recommended Citation \\ Hussain, C.M., Duffy, A., \& Norton, B. (2019). Economic appraisal of hybrid solar-biomass thermophotovoltaic power generation. Proceedings of the Institution of Civil Engineers - Energy. DOI:10.1680/JENER.19.00023}

This Conference Paper is brought to you for free and open access by the Dublin Energy Lab at ARROW@TU Dublin. It has been accepted for inclusion in Conference Papers by an authorized administrator of ARROW@TU

Dublin. For more information, please contact

arrow.admin@tudublin.ie, aisling.coyne@tudublin.ie, gerard.connolly@tudublin.ie.

Funder: Technological University Dublin

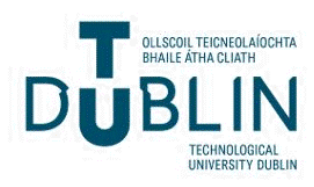




\title{
Economic appraisal of hybrid solar-biomass thermophotovoltaic power generation
}

\author{
Choudhury Mohammad Iftekhar Hussain MSC \\ PhD student, Dublin Energy Lab, Technological University Dublin, Dublin, \\ Ireland (corresponding author: iftekhar.hussain@mydit.ie) \\ Aidan Duffy PhD \\ Senior Lecturer, Dublin Energy Lab, Technological University Dublin, \\ Dublin, Ireland
}

\author{
Brian Norton PhD \\ Principal, TU Dublin, Dublin Energy Lab, Technological University Dublin, \\ Dublin, Ireland
}

\begin{abstract}
The techno-economic parameters that influence the commercial deployment of hybrid thermophotovoltaic (TPV) solar power generation are determined using annual system simulations. It has been found that a TPV cell price of $€ 5 / \mathrm{cm}^{2}$ or less together with a TPV operating temperature under $800^{\circ} \mathrm{C}$ is required for a hybrid solar-biomass TPV power plant to be economically competitive with the state-of-the-art hybrid solar-biomass Rankine cycle power plants.
\end{abstract}

\section{Introduction}

A solar thermophotovoltaic (TPV) device comprises a solar heated surface from which heat is conducted to a surface that emits thermal radiation converted directly to electricity by a TPV cell as shown in Figure 1 (Daneshvar et al., 2015; Ferrari et al., 2014; Mustafa et al., 2017).

By incorporating additional appropriate components, a TPV system can also harness energy from biomass/gas combustion, stored heat or waste heat to overcome the intermittency in the output associated with a stand-alone solar power plant (Datas, 2016; Hussain et al., 2017). A conceptual diagram of a hybrid solar-biomass TPV system combining the direct use of solar energy with biomass combustion is shown in Figure 2.

The analysis presented here seeks to determine the key parameter values for a hybrid solar-biomass TPV power plant that are required to be achieved for competitiveness with a conventional solar-biomass power generation option. Levelised cost of electricity (LCOE) is chosen to compare the projected economic viability of different hybrid solar-biomass power generation systems. The LCOE is set by two variables: (a) TPV cell price $/ \mathrm{cm}^{2}$ and $(b)$ annual biomass fuel expenditure. A threshold economically viable TPV cell price is determined by varying the TPV cell cost. LCOEs for TPV power plants operating at different TPV temperatures are evaluated by varying biomass fuel expenditure.

\section{Background}

Previous studies have presented economic analyses of concentrated solar power (CSP)-thermal energy storage (TES) power plants (Guédez, 2016; Locatelli et al., 2015; Naranjo et al., 2014; Wagner and Rubin, 2014). A hybrid solar-biomass Rankine cycle power plant has been compared with hybrid solar-biomass-TES Rankine cycle power plants to determine the most economically viable hybrid power plant configuration (Hussain, 2019). In that study, a stand-alone biomass system was simulated to obtain annual fuel expenditure; a hybrid CSP-biomass power plant and a hybrid CSP-biomass-TES Rankine cycle power plant were then simulated to compare fuel consumptions for the same electrical power output. It was found that a hybrid CSP-biomass Rankine cycle power plant was more economically viable than a hybrid CSPbiomass-TES power generation option. The baseline annual biomass fuel cost for a CSP-biomass power plant was found to be $€ 132 / \mathrm{kW}$ at an operating temperature of $400^{\circ} \mathrm{C}$ (Hussain, 2019). The annual fuel price was obtained from a simulation that calculated cumulative fuel prices over 20 years of plant lifetime operating $357 \mathrm{~d} /$ year (with $8 \mathrm{~d} /$ year shut down for maintenance); equivalent to $€ 0 \cdot 015 / \mathrm{kWh}$. A hybrid solar-biomass power plant fuel cost was combined with an initial capital expenditure, capacity factor, discount rate and fixed and variable costs to obtain the LCOE. In this study, a LCOE of $€ 0 \cdot 139 / \mathrm{kWh}$ was obtained from the annual biomass fuel consumption of $€ 132 / \mathrm{kW}$.

$€ 50 / \mathrm{cm}^{2}$ (€10 416/kW) is an indicative current cost of a highband-gap TPV cell (Fraas et al., 2014). This TPV cell price is high due to the limited volume of TPV cell production. Previous studies have shown that TPV cell production volume above $1 \mathrm{MW} /$ year could bring the prices to commercially viable levels (Fraas, 2014). With the production volume increasing from $10 \mathrm{~kW}$ to $100 \mathrm{MW}$, TPV cell cost has been estimated to decrease significantly from approximately $€ 9000 / \mathrm{kW}$ to $€ 270 / \mathrm{kW}$ as illustrated in Figure 3 (Fraas et al., 2014). Photovoltaic (PV) cells have experienced an almost similar price reduction trend with increased production volumes (Feldman et al., 2012). Fraas et al. (2014) evaluated the cost-reduction trend of TPV cell using data sets presented in previous studies. As can be seen in Figure 3, a price of 


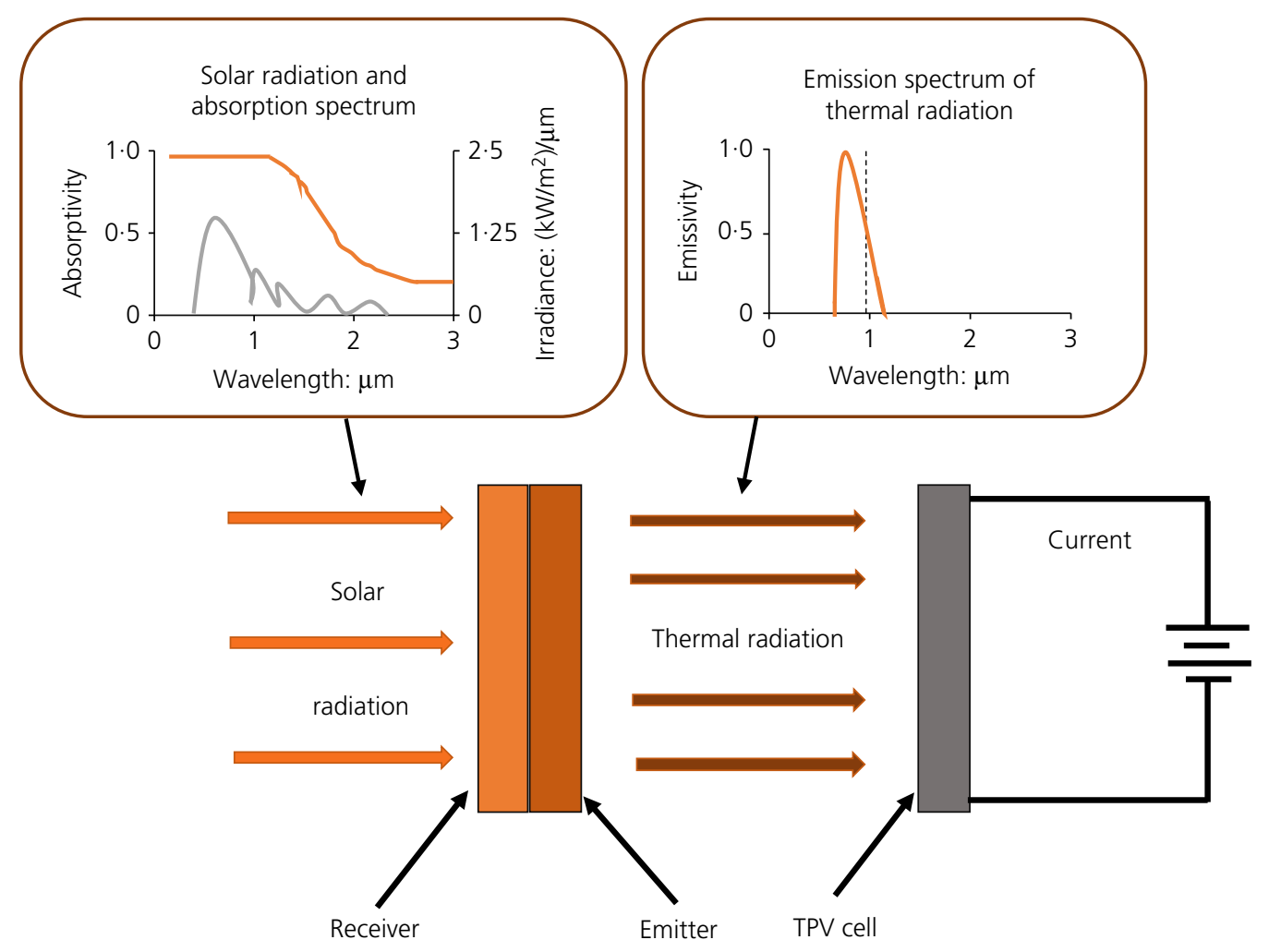

Figure 1. Solar TPV system

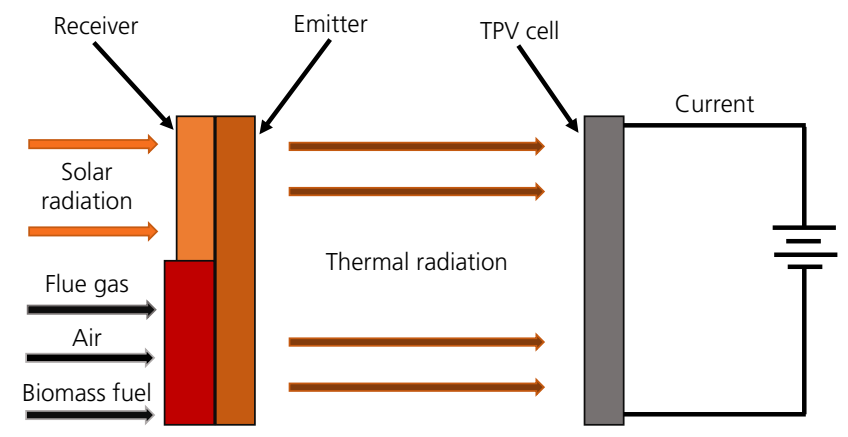

Figure 2. A hybrid solar-biomass TPV system concept

approximately $€ 5000 / \mathrm{kW}$ represents a production volume of $300 \mathrm{~kW} /$ year which further reduces to approximately $€ 500 / \mathrm{kW}$ when the production volume is increased to $10 \mathrm{MW} / \mathrm{year}$.

\section{Cost parameters}

Assuming that the economies of scale in production, illustrated in Figure 3, do provide a substantial future cost reduction, the TPV cell prices of $(a) € 10 / \mathrm{cm}^{2},(b) € 5 / \mathrm{cm}^{2}$ and $(c) € 1 \cdot 25 / \mathrm{cm}^{2}$ were assumed. A TPV cell price of $€ 10 / \mathrm{cm}^{2}$ was calculated to be equivalent to a $€ 2083 / \mathrm{kW}$ installed cost. $A € 5 / \mathrm{cm}^{2} \mathrm{TPV}$

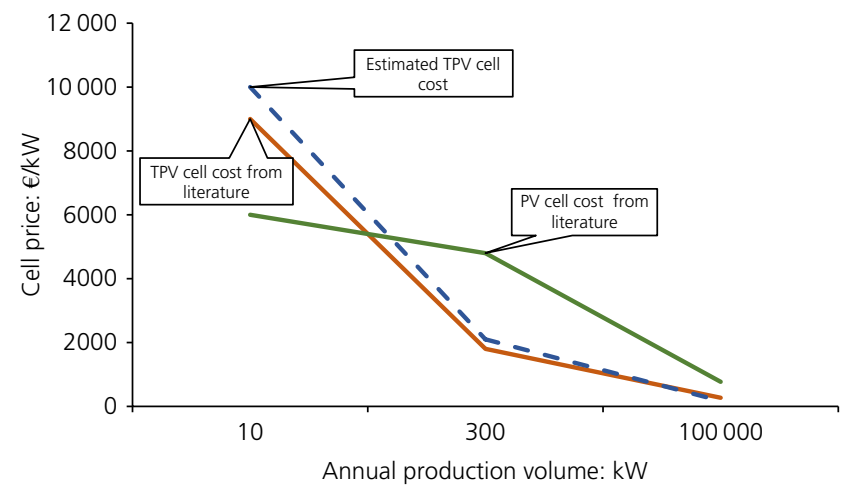

Figure 3. Potential cost reduction of TPV cells with increased production (source: Feldman et al. (2012), Fraas et al. (2014))

cell was equivalent to $€ 1041 \mathrm{~kW}$ installed cost, and $€ 1 \cdot 25 / \mathrm{cm}^{2}$ TPV was equivalent to the installed cost of $€ 260 / \mathrm{kW}$, illustrated in Figure 3 (calculated in Table 1).

A CSP-biomass Rankine cycle power plant model operating at $400^{\circ} \mathrm{C}$ was simulated using TRNSYS 17 software. This work used the fuel consumption profile from a relevant previous study (Hussain, 2019; Perilhon et al., 2012) with fuel costs extrapolated 
Table 1. Economic parameters for hybrid TPV-based solar-biomass power plants

\begin{tabular}{|c|c|c|c|c|}
\hline & \multicolumn{4}{|c|}{ TPV cost } \\
\hline & $€ 1 \cdot 25 / \mathrm{cm}^{2}$ & $€ 5 / \mathrm{cm}^{2}$ & $€ 10 / \mathrm{cm}^{2}$ & $€ 50 / \mathrm{cm}^{2}$ \\
\hline \multicolumn{5}{|l|}{ Input cost } \\
\hline Solar + biomass installed cost: $€ / k W$ & 7000 & & & \\
\hline Solar + biomass installed total cost: $€$ & 8400000 & & & \\
\hline Other fixed costs: $(€ / \mathrm{kW}) /$ year & 200 & & & \\
\hline Operation and maintenance costs: $(€ / \mathrm{kW}) /$ year & 50 & & & \\
\hline \multicolumn{5}{|l|}{ Economic parameters } \\
\hline Discount rate: \% & 9 & & & \\
\hline Capacity factor: \% & 85 & & & \\
\hline Plant capacity: kW & 1200 & & & \\
\hline Plant lifetime: years & 20 & & & \\
\hline \multicolumn{5}{|l|}{ Output system costs } \\
\hline Total TPV cost: $€$ for $250000 \mathrm{~cm}^{2}$ area & 312500 & 1250000 & 2500000 & 12500000 \\
\hline TPV cell cost: $€ / k W$ & 260 & 1041 & 2083 & 10416 \\
\hline Total investment cost: $€$ & 8712500 & 9650000 & 10900000 & 20900000 \\
\hline Overall energy cost: $€ / \mathrm{kW}$ & 7260 & 8041 & 9083 & 17416 \\
\hline
\end{tabular}

Bold/italic numbers indicate installed TPV cell cost obtained from validated results as presented in Figure 3

for higher-temperature TPV processes, as a solar-biomass TPV power plant operates at a higher temperature than a hybrid CSP-biomass Rankine cycle power plant. As current commercially available TPV cells have high band gaps that require high temperatures to operate optimally, this study considered higher system operating temperatures at 800 and $1200^{\circ} \mathrm{C}$. The annual fuel costs for a TPV-based hybrid power plant were assumed to be $(a)$ at $€ 264 / \mathrm{kW}$ (or $€ 0.031 / \mathrm{kWh}$ ) for $800^{\circ} \mathrm{C}$ and $(b)$ at $€ 396 / \mathrm{kW}$ (or $€ 0 \cdot 046 / \mathrm{kWh}$ ) for $1200^{\circ} \mathrm{C}$. In a low-band-gap TPV cell, a higher power output can be obtained at a lower temperature (Chubb, 2007). This would approximately maintain a steady power output of a TPV-based power plant when considering power plant operation at different temperature ranges (Hussain, 2019). The maximum capacity of the TPV-based hybrid power plants studied in this work was assumed to be $1200 \mathrm{~kW}$.

A solar tower concentrator power plant comprises tracking heliostats that concentrate solar radiation on a tower-located absorber. These, together with the cost of the required land and construction, give a capital expenditure estimated to be $€ 3575 / \mathrm{kW}$ (Turchi, 2017). The installation cost of a biomass power plant was estimated to be $€ 3500 / \mathrm{kW}$ (KAPSARC, 2014). Assuming savings of $€ 75 / \mathrm{kW}$ arising from common shared equipment in a combined plant, this study calculated the overall capital expenditure would be $€ 7000 / \mathrm{kW}$ for a hybrid solar CSP-biomass TPV power plant.

\section{Economic analysis of a hybrid solar-biomass TPV power plant}

\subsection{Methodology}

Power of $1200 \mathrm{~kW}$ was generated by a TPV cell area of $250000 \mathrm{~cm}^{2}$ as calculated using a TRNSYS 17 simulation model. At $€ 1 \cdot 25 / \mathrm{cm}^{2}$, the total cost of the TPV cell was estimated to be $€ 312500$, giving a TPV cell unit price of $€ 260 / \mathrm{kW}$. Therefore, the overall capital cost of a solarbiomass TPV power plant was estimated to be $€ 7260 / \mathrm{kW}$ (i.e. capital expenditure of the solar-biomass power plant $/ \mathrm{kW}+$ TPV cell price $/ \mathrm{kW}=€ 7000 / \mathrm{kW}+€ 260 / \mathrm{kW})$. Similarly the capital costs were estimated as $(a) € 8041 / \mathrm{kW}$ for TPV cell cost $€ 5 / \mathrm{cm}^{2}$, (b) $€ 9083 / \mathrm{kW}$ for TPV cell cost $€ 10 / \mathrm{cm}^{2}$ and (c) $€ 17416 / \mathrm{kW}$ for TPV cell cost $€ 50 / \mathrm{cm}^{2}$. The system cost breakdown with different TPV cell prices is given in Table 1 . The systems in Table 1 were each considered with annual fuel costs obtained from simulations of $€ 132$, €264 and $€ 396 / \mathrm{kW}$.

\subsection{LCOE and sensitivity analysis of a hybrid solar-biomass TPV power plant}

The LCOEs for the hybrid solar-biomass TPV power plant are ranked on the basis of (a) TPV cell price $/ \mathrm{cm}^{2}$ and (b) biomass annual fuel expenditure in Table 2.

The biomass fuel expenditure in Table 2 varied according to the amount of fuel consumed to maintain the required combustion temperature. High combustion temperature incurred higher biomass fuel expenditure, whereas lower-temperature operation required less fuel.

The LCOE of the hybrid power plant with a TPV cell price $€ 50 / \mathrm{cm}^{2}$ combined with any of the biomass fuel cost variations was found to be above $€ 0 \cdot 3 / \mathrm{kWh}$ as shown in Table 2 . In previous studies, the LCOE of the state-of-the art hybrid CSP-biomass power plant was found to be in the range of $€ 0 \cdot 139-€ 0 \cdot 175 / \mathrm{kWh}$ (Hussain, 2019; Servert and Miguel, 2011; Soares et al., 2018). Thus, an LCOE above $€ 0 \cdot 3 / \mathrm{kWh}$ 
Table 2. LCOE in $€ / k W h$ of different hybrid TPV power plant configurations with varying economic parameters

\begin{tabular}{|c|c|c|c|}
\hline Operating temperature & $400^{\circ} \mathrm{C}$ & $800^{\circ} \mathrm{C}$ & $1200^{\circ} \mathrm{C}$ \\
\hline Annual biomass fuel cost & $€ 132 / \mathrm{kW}$ & $€ 264 / \mathrm{kW}$ & $€ 396 / \mathrm{kW}$ \\
\hline \multicolumn{4}{|l|}{ TPV cell price } \\
\hline$€ 1 \cdot 25 / \mathrm{cm}^{2}$ & $0 \cdot 16$ & $0 \cdot 18$ & $0 \cdot 20$ \\
\hline$€ 5 / \mathrm{cm}^{2}$ & $0 \cdot 17$ & $0 \cdot 19$ & 0.21 \\
\hline$€ 10 / \mathrm{cm}^{2}$ & $0 \cdot 19$ & 0.21 & 0.23 \\
\hline$€ 50 / \mathrm{cm}^{2}$ & $0 \cdot 31$ & 0.33 & 0.35 \\
\hline
\end{tabular}

Table 3. Variation of LCOE of different TPV hybrid plant configurations with fixed fuel price

\begin{tabular}{|c|c|c|c|c|c|c|c|c|c|}
\hline & \multicolumn{9}{|c|}{ Annual fuel expenditure: $€ 264 / \mathrm{kW}$, operating temperature at $800^{\circ} \mathrm{C}$} \\
\hline & \multicolumn{3}{|c|}{ TPV cost: $€ 1 \cdot 25 / \mathrm{cm}^{2}$} & \multicolumn{3}{|c|}{ TPV cost: $€ 5 / \mathrm{cm}^{2}$} & \multicolumn{3}{|c|}{ TPV cost: $€ 10 / \mathrm{cm}^{2}$} \\
\hline & $\begin{array}{l}\text { Lower } \\
\text { limit }\end{array}$ & $\begin{array}{l}\text { Base- } \\
\text { case }\end{array}$ & $\begin{array}{l}\text { Upper } \\
\text { limit }\end{array}$ & $\begin{array}{l}\text { Lower } \\
\text { limit }\end{array}$ & $\begin{array}{l}\text { Base- } \\
\text { case }\end{array}$ & $\begin{array}{l}\text { Upper } \\
\text { limit }\end{array}$ & $\begin{array}{l}\text { Lower } \\
\text { limit }\end{array}$ & $\begin{array}{l}\text { Base- } \\
\text { case }\end{array}$ & $\begin{array}{l}\text { Upper } \\
\text { limit }\end{array}$ \\
\hline Capacity factor: \% & 90 & 80 & 70 & 90 & 80 & 70 & 90 & 80 & 70 \\
\hline LCOE: €/kWh & 0.166 & 0.183 & 0.194 & 0.177 & 0.195 & 0.217 & 0.191 & 0.210 & 0.234 \\
\hline Discount rate: \% & 14 & 9 & 4 & 14 & 9 & 4 & 14 & 9 & 4 \\
\hline LCOE: €/kWh & $0 \cdot 150$ & 0.183 & 0.219 & $0 \cdot 160$ & 0.195 & 0.236 & 0.170 & 0.210 & 0.257 \\
\hline Capital cost: $€ / \mathrm{kW}$ & 6534 & 7260 & 7986 & 7237 & 8041 & 8845 & 8175 & 9083 & 9991 \\
\hline LCOE: €/kWh & 0.163 & 0.183 & 0.193 & 0.183 & 0.195 & 0.207 & 0.197 & 0.210 & 0.223 \\
\hline
\end{tabular}

Bold/italic numbers indicate installed TPV cell cost obtained from validated results as presented in Figure 3

might not be economically viable for TPV technology to be integrated into a commercial-scale hybrid power plant. TPV cell price at $€ 10 / \mathrm{cm}^{2}$ with an annual biomass fuel price of $€ 396 / \mathrm{kW}$ (for $1200^{\circ} \mathrm{C}$ ) gave an LCOE of $€ 0.23 / \mathrm{kWh}$. The reduction of the annual fuel price of $€ 132 / \mathrm{kW}$ (when operated at $400^{\circ} \mathrm{C}$ ) could give a better LCOE of $€ 0 \cdot 19 / \mathrm{kWh}$. A TPV cell price of $€ 5 / \mathrm{cm}^{2}$ with an annual biomass fuel expenditure of $€ 396 / \mathrm{kW}$ produced an LCOE of $0 \cdot 21 / \mathrm{kWh}$ that was found to be higher than the LCOE of the state-of-the-art hybrid CSP-biomass power plant. However, the LCOE was found to be much more economically competitive when the system operated at lower temperatures. For example, the LCOE with a TPV cell price of $€ 5 / \mathrm{cm}^{2}$ was found to be $€ 0 \cdot 19 / \mathrm{kWh}$ when it was operated at $800^{\circ} \mathrm{C}$ and $€ 0 \cdot 17 / \mathrm{kWh}$ when operated at $400^{\circ} \mathrm{C}$. A TPV price of $€ 1 \cdot 25 / \mathrm{cm}^{2}$ with lower TPV temperatures further improved the LCOE.

Although an annual fuel expenditure of $€ 132 / \mathrm{kW}$ (at an operating temperature of $400^{\circ} \mathrm{C}$ ) produced a lower LCOE, a TPV cell operating at such a lower TPV temperature is not commercially available. A low-band-gap TPV cell is under development that could enable a TPV operation at a low temperature under $800^{\circ} \mathrm{C}$ (Krier et al., 2016). Therefore, in Table 3 systems with different TPV cell prices were compared along with a moderate fuel price of $€ 264$ applied at an operating temperature at $800^{\circ} \mathrm{C}$.
The 'base-case' column presents the LCOE obtained with an $80 \%$ capacity factor and a $9 \%$ discount rate. The columns 'upper limit' and 'lower limit' indicate realistic upper and lower limits, respectively, for LCOE, when the capacity factor is varied by $10 \%$, the discount rate is varied by $5 \%$ and the capital cost is varied by $10 \%$. The base-case LCOE of hybrid TPV power plants was approximately 31-51\% (from $€ 0 \cdot 183 \mathrm{kWh}$ for $€ 1 \cdot 25 / \mathrm{cm}^{2}$ to $€ 0 \cdot 21 \mathrm{kWh}$ for $€ 10 / \mathrm{cm}^{2}$ ) higher than the base-case LCOE of the hybrid CSP-biomass Rankine cycle power plant $(€ 0 \cdot 139 \mathrm{kWh})$. A discount rate of $14 \%$ reduced the difference to between 8 and $22 \%$ (from $€ 0 \cdot 150$ to $€ 0 \cdot 170 \mathrm{kWh}$ ) as shown in Table 3. A $10 \%$ variation of the capacity factor and the initial capital cost did not affect LCOE as significantly as it was affected by the change in the discount rate. Percentage variations of LCOE due to the changes in different techno-economic parameters are presented in Figure 4. As it can be seen, the best case was found with the TPV cell being operated at $800^{\circ} \mathrm{C}$ at a price of $€ 1 \cdot 25 / \mathrm{cm}^{2}$.

For a $€ 5 / \mathrm{cm}^{2} \mathrm{TPV}$ cell price, the changes in LCOE from different annual biomass fuel expenditures due to different temperature operations are shown in Table 4. Annual biomass fuel expenditure of $€ 396 / \mathrm{kW}$ produced an LCOE of $€ 0 \cdot 215 / \mathrm{kWh}$ as shown in Table 4 . The LCOE is low when the cost of fuel consumed is low; an LCOE of $€ 0 \cdot 195 / \mathrm{kWh}$ corresponded to an annual fuel expenditure of $€ 264 / \mathrm{kW}$, while an 


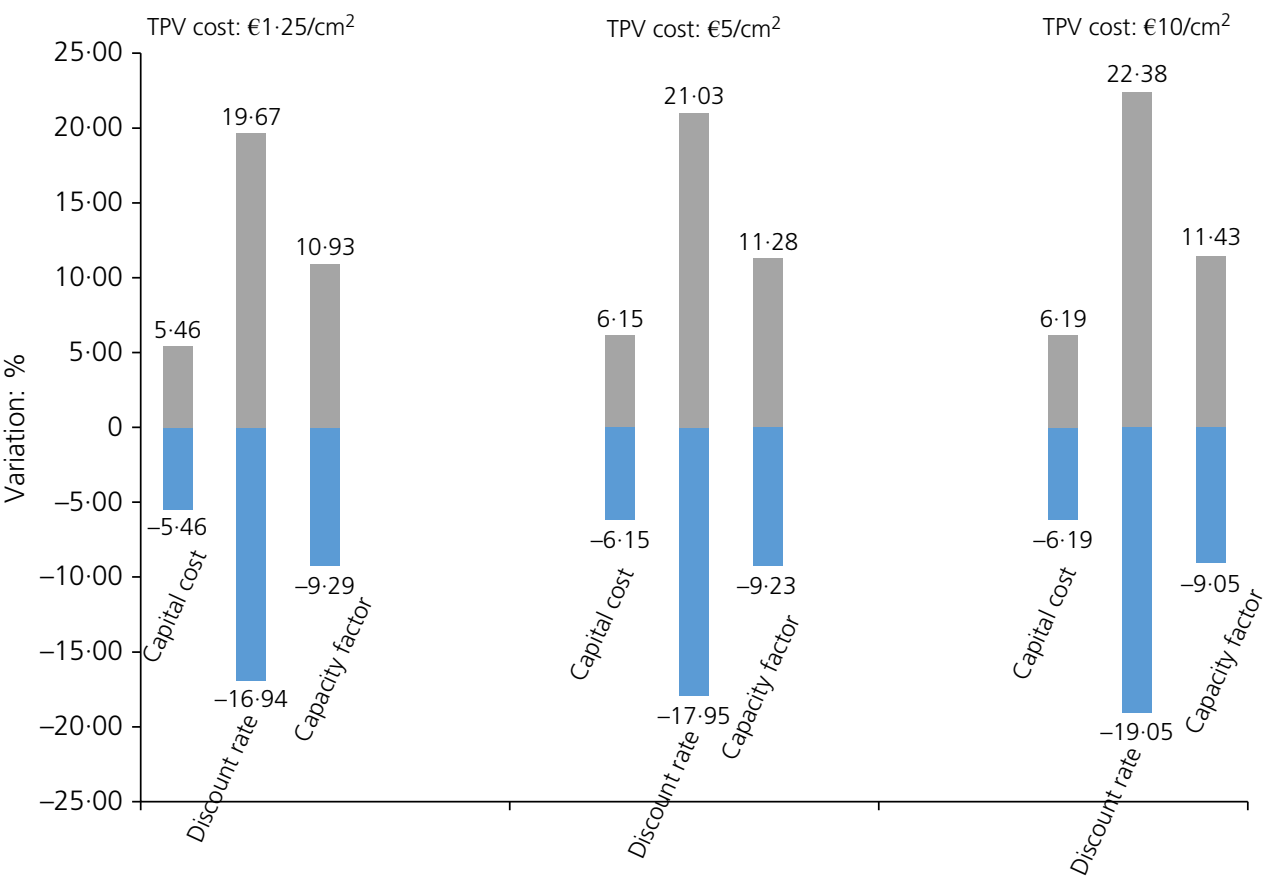

Figure 4. Percentage variation of LCOE of a hybrid TPV power plant with variable TPV cell price at an operating temperature of $800^{\circ} \mathrm{C}$

Table 4. Variation of LCOE of different TPV hybrid plant configurations with fixed TPV cell price

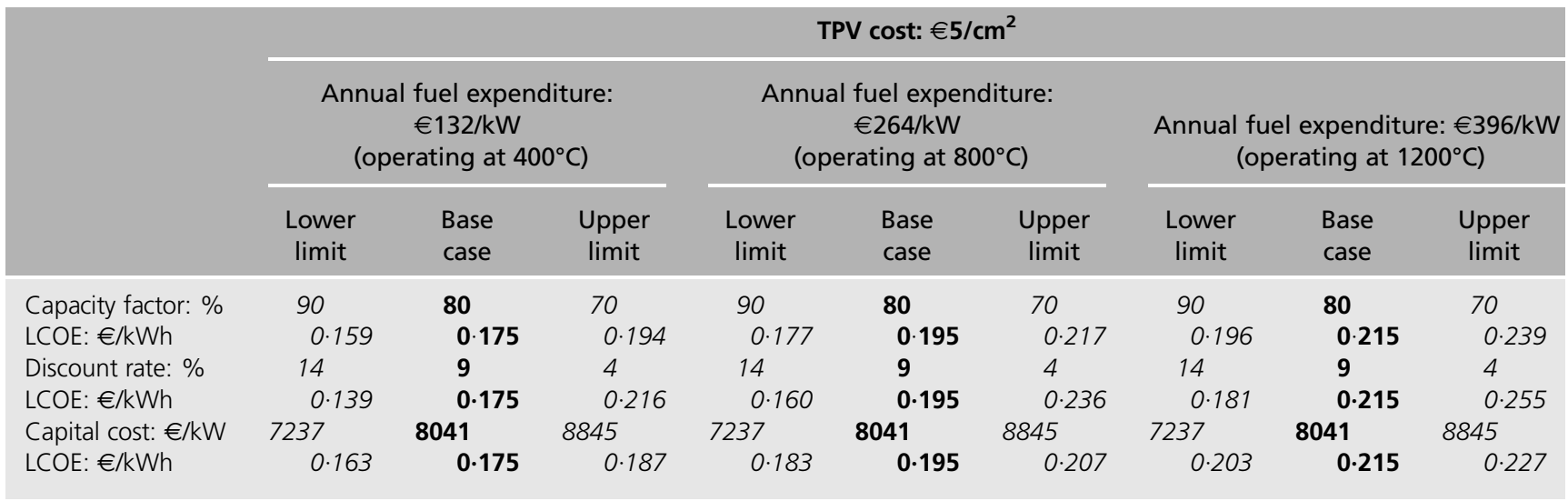

Bold/italic numbers indicate installed TPV cell cost obtained from validated results as presented in Figure 3

LCOE of $€ 0 \cdot 175 / \mathrm{kWh}$ corresponded to an annual fuel expenditure of $€ 132 / \mathrm{kW}$.

When the annual fuel cost of $€ 132 / \mathrm{kW}$ was chosen, a $20 \cdot 57 \%$ reduction from base-case LCOE of $€ 0 \cdot 175 / \mathrm{kWh}$ could make a solar-biomass TPV power plant potentially economically viable in the present hybrid power generation scenario (with a low LCOE of $€ 0 \cdot 139 / \mathrm{kW}$ ), as can be seen in Figure 5 . Variations of the capacity factor and the capital cost produced comparatively minor changes to the LCOE.

\subsection{Rankine cycle and TPV systems comparison for solar-biomass hybridisation}

The LCOE of a hybrid CSP-biomass Rankine cycle power generation system was compared with the LCOEs of a TPV-based hybrid solar-biomass power generation system. For the comparison, the two most promising TPV options given in Tables 3 and 4 were compared with the base-case LCOE of $€ 0 \cdot 139 / \mathrm{kWh}$ for the hybrid CSP-biomass Rankine cycle power plant (Hussain, 2019). The comparative results for two hybrid TPV-biomass systems and one 


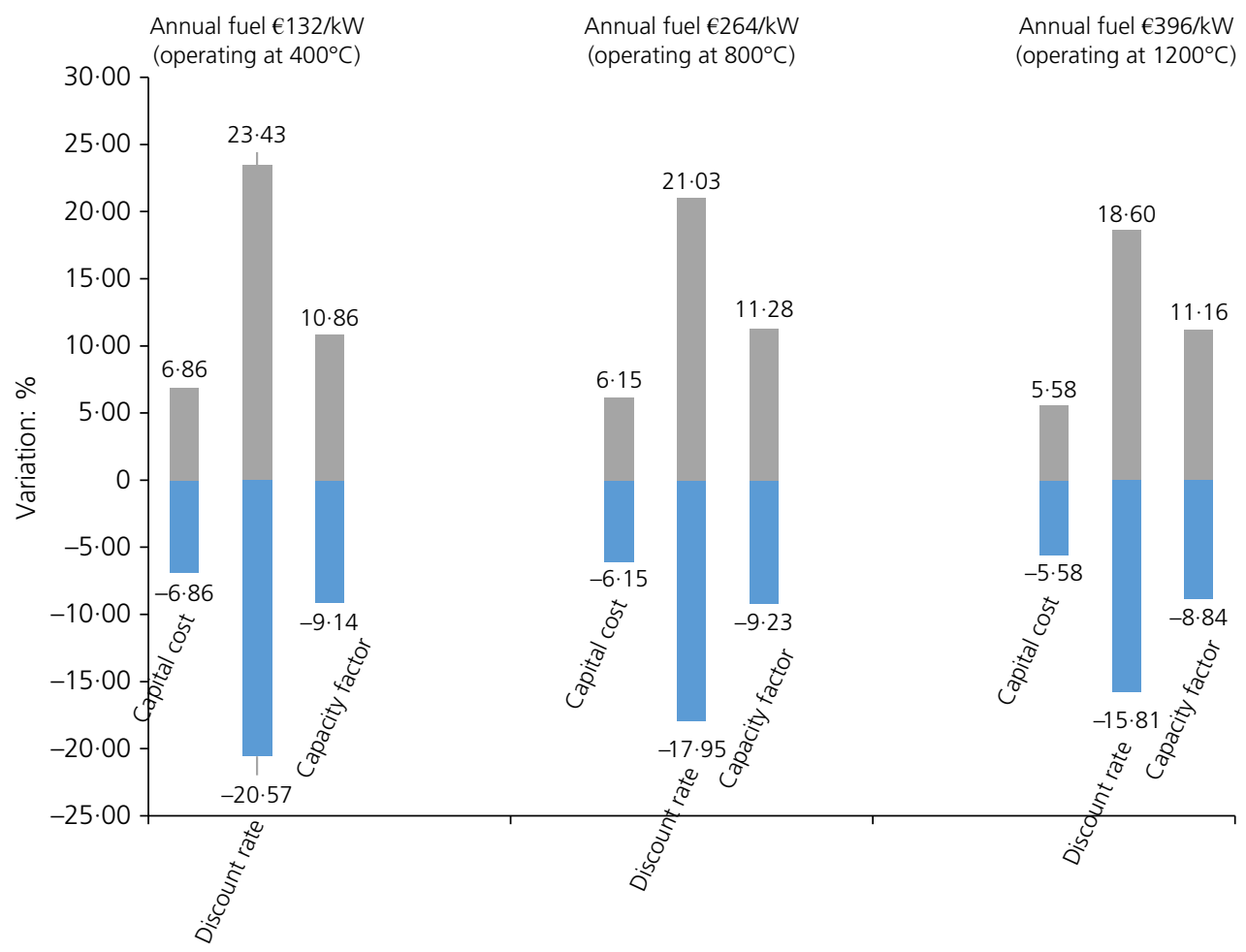

Figure 5. Percentage variation of LCOE of a hybrid TPV power plant with variable fuel expenditure

Table 5. LCOE comparison of CSP and TPV-based hybrid power plant

\begin{tabular}{|c|c|c|c|c|c|c|c|c|c|}
\hline & & & & \multicolumn{6}{|c|}{ Solar-biomass TPV } \\
\hline & & & & & cost: $€ 1 \cdot 2$ & & & $V$ cost $: € 5$ & \\
\hline & \multicolumn{3}{|c|}{ CSP-biomass Rankine cycle } & \multicolumn{3}{|c|}{$\begin{array}{l}\text { Annual fuel expenditure: } € 264 / \mathrm{kW} \\
\text { (operating at } 800^{\circ} \mathrm{C} \text { ) }\end{array}$} & \multicolumn{3}{|c|}{$\begin{array}{l}\text { Annual fuel expenditure: } € 132 / \mathrm{kW} \\
\text { (operating at } 400^{\circ} \mathrm{C} \text { ) }\end{array}$} \\
\hline & $\begin{array}{l}\text { Lower } \\
\text { limit }\end{array}$ & $\begin{array}{l}\text { Base- } \\
\text { case }\end{array}$ & $\begin{array}{l}\text { Upper } \\
\text { limit }\end{array}$ & $\begin{array}{l}\text { Lower } \\
\text { limit }\end{array}$ & $\begin{array}{l}\text { Base- } \\
\text { case }\end{array}$ & $\begin{array}{l}\text { Upper } \\
\text { limit }\end{array}$ & $\begin{array}{l}\text { Lower } \\
\text { limit }\end{array}$ & $\begin{array}{l}\text { Base- } \\
\text { case }\end{array}$ & $\begin{array}{l}\text { Upper } \\
\text { limit }\end{array}$ \\
\hline Capacity factor: \% & 90 & 80 & 70 & 90 & 80 & 70 & 90 & 80 & 70 \\
\hline LCOE: €/kWh & 0.126 & 0.139 & 0.154 & $0 \cdot 166$ & 0.183 & $0 \cdot 194$ & 0.159 & 0.175 & 0.194 \\
\hline Discount rate: \% & 14 & 9 & 4 & 14 & 9 & 4 & 14 & 9 & 4 \\
\hline LCOE: €/kWh & 0.112 & 0.139 & 0.169 & 0.150 & 0.183 & 0.219 & 0.139 & 0.175 & 0.216 \\
\hline Capital cost: $€ / \mathrm{kW}$ & 5400 & 6000 & 6600 & 6534 & 7260 & 7986 & 7237 & 8041 & 8845 \\
\hline LCOE: €/kWh & 0.130 & 0.139 & 0.147 & 0.163 & 0.183 & 0.193 & 0.163 & 0.175 & 0.187 \\
\hline
\end{tabular}

Bold/italic numbers indicate installed TPV cell cost obtained from validated results as presented in Figure 3

hybrid CSP-biomass Rankine cycle system are illustrated in Table 5 .

The base-case LCOE of both hybrid TPV-biomass power plants were higher than the CSP Rankine cycle hybrid power plant in Table 5. However, the lower-limit LCOEs of both TPV-based power plant configurations were economically competitive with the hybrid economical power plant with an LCOE of $€ 0 \cdot 139 / \mathrm{kWh}$. The lowest LCOE of $€ 0 \cdot 139 / \mathrm{kWh}$ for a TPV-based hybrid solar-biomass power plant was found at a TPV cell cost of $€ 5 / \mathrm{cm}^{2}$ when operated at a lower operating temperature of $400^{\circ} \mathrm{C}$, leading to a lower annual fuel expenditure of $€ 132 / \mathrm{kW}$ at a discount rate of $14 \%$. 


\section{Conclusions}

Biomass fuel consumption is directly related to the temperature required to use specific TPV cells. Therefore, using a lowband-gap TPV cell to operate a TPV system below $800^{\circ} \mathrm{C}$ incurs lower annual biomass fuel expenditure. Assuming other economic factors remain constant, a TPV cell which costs below $€ 5 / \mathrm{cm}^{2}$ is essential before solar TPV technology can be viable for deployment for solar thermal electric power generation.

\section{Acknowledgement}

The authors appreciate the financial support provided by the Technological University Dublin under the Fiosraigh research scholarship scheme.

\section{REFERENCES}

Chubb DL (2007) Fundamentals of Thermophotovoltaic Energy Conversion. Elsevier, Nasa-Glenn Research Center, Cleveland, $\mathrm{OH}, \mathrm{USA}$.

Daneshvar H, Prinja R and Kherani NP (2015) Thermophotovoltaics: fundamentals, challenges and prospects. Applied Energy 159: $560-575$.

Datas A (2016) Hybrid thermionic-photovoltaic converter. Applied Physics Letters 108(14): 143503.

Feldman D, Barbose G, Wiser R, Darghouth N and Goodrich A (2012) Photovoltaic (PV) Pricing Trends: Historical, Recent, and Near-Term Projections. SunShot, US Department of Energy, Golden, CO, USA.

Ferrari C, Melino F, Pinelli M and Spina PR (2014) Thermophotovoltaic energy conversion: analytical aspects, prototypes and experiences. Applied Energy 113: 1717-1730.

Fraas LM (2014) Economic potential for thermophotovoltaic electric power generation in the steel industry. IEEE 40th Photovoltaic Specialist Conference (PVSC), Denver, CO, USA, pp. 0766-0770.

Fraas L, Minkin L, Avery J and She H (2014) Lightweight fuel-fired thermophotovoltaic power supply. 31st European Photovoltaic Solar Energy Conference and Exhibition, Hamburg, Germany, pp. 2690-2695.

Guédez R (2016) A Techno-Economic Framework for the Analysis of Concentrating Solar Power Plants with Storage. PhD thesis, KTH Royal Institute of Technology, Stockholm, Sweden.

Hussain CMI (2019) Hybrid Solar-Biomass Power Generation System. $\mathrm{PhD}$ thesis, Technological University Dublin, Dublin, Ireland.

Hussain CMI, Norton B, Duffy A and Oubaha M (2017) Conceptual design of a solar thermophotovoltaic-biomass/gas power generation system and development method of a spectrally matched emitter for lower operating temperature. 12th Conference on Sustainable Development of Energy, Water and Environment Systems, Dubrovnik, Croatia, paper no. SDEWES2017.0563.

KAPSARC (King Abdullah Petroleum Studies and Research Center) (2014) A Framework for Fuel and Technology Transitions in Energy: Evaluating Policy Effectiveness. KAPSARC, Riyadh, Saudi Arabia, Workshop Policy Brief. See https://www.kapsarc. org/research/publications/a-framework-for-fuel-and-technologytransitions-in-energy-evaluating-policy-effectiveness/ (accessed 13/07/2018).

Krier A, Yin M, Marshall ARJ and Krier SE (2016) Low bandgap InAs-base thermophotovoltaic cells for heat-electricity conversion. Journal of Electron Materials 45(6): 2826-2830.
Locatelli G, Palerma E and Mancini M (2015) Assessing the economics of large energy storage plants with an optimisation methodology. Energy 83: 15-28, https://doi.org/10.1016/j.energy. 2015.01.050.

Mustafa KF, Abdullahb S, Abdullaha MZ and Sopian. K (2017) A review of combustion-driven thermoelectric (TE) and thermophotovoltaic (TPV) power systems. Renewable and Sustainable Energy Reviews 71: $572-584$.

Naranjo PS, Valentine KF, Wong M and Zhang KM (2014) Reducing power system costs with thermal energy storage. Applied Energy 129: 228-237.

Perilhon C, Alkadee D, Descombes G and Lacour S (2012) Life cycle assessment applied to electricity generation from renewable biomass. Energy Procedia 18: 165-176.

Servert J and Miguel GS (2011) Hybrid solar-biomass plants for power generation; technical and economic assessment. Global NEST Journal 13(3): 266-276.

Soares J, Oliveira AC, Dieckmann S, Krüger D and Orioli F (2018) Evaluation of the performance of hybrid CSP/biomass power plants. International Journal of Low-Carbon Technologies 13(4): 380-387.

Turchi C (2017) Concentrating Solar Power: Current Cost and Future Directions. NREL, Golden, CO, USA. See http://atainsights. com/wp-content/uploads/2017/05/Craig-PPT.pdf (accessed 12/07/ 2018).

Wagner SJ and Rubin ES (2014) Economic implications of thermal energy storage for concentrated solar thermal power. Renewable Energy 61: 81-95.

\section{How can you contribute?}

To discuss this paper, please email up to 500 words to the editor at journals@ice.org.uk. Your contribution will be forwarded to the author(s) for a reply and, if considered appropriate by the editorial board, it will be published as discussion in a future issue of the journal.

Proceedings journals rely entirely on contributions from the civil engineering profession (and allied disciplines). Information about how to submit your paper online is available at www.icevirtuallibrary.com/page/authors, where you will also find detailed author guidelines. 